\title{
PENGARUH PENGGUNAAN MASKER JAGUNG DAN MADU TERHADAP PERAWATAN KULIT WAJAH KERING
}

\author{
Atika Fatmawati ${ }^{1)}$ dan Susilowati ${ }^{2)}$ \\ ${ }^{1,2}$ Pendidikan vokasional Kesejahteraan Keluarga - Tata Rias. Fakultas Keguruan dan Ilmu Pendidikan \\ Universitas PGRI Adi Buana Surabaya \\ Email: Atika.7f5@gmail.com ${ }^{1}$
}

\begin{abstract}
Abstrak
Jagung selain dapat di olah menjadi makanan pokok dan makanan hewan ternak ternyata menyimpan berbagai manfaat yang baik untuk perawatan kecantikan. Salah satu olahan jagung yang dapat di manfaatkan ialah pembuatan masker jagung dan madu untuk perawatan kulit wajah kering. Penelitian ini bertujuan untuk mengetahui bagaimana sifat fisik masker jagung dan madu yang meliputi warna, aroma, terkstur, dan kesukaan panelis, menganalisis pengaruh masker jagung dan madu terhadap perawatan kulit wajah kering di tinjau dari tekstur kulit, kelembaban kulit, elastisitas kulit dan menentukan tanggapan observer terhadap masker dan perawatan kulit wajah kering. Jenis penelitian ini kuantitafi dengan menggunakan metode observasi dan eksperimen. Populasi dalam penelitian ini wanita usia 20-25 Tahun. Metode pengumpulan data menggunakan observasi dan uji kesukaan panelis terhadap warna, aroma, tekstur, daya lekat sejumlah 10 responden.. Hasil penelitian menunjukkan ada pengaruh penggunaan masker jagung dan madu terhadap perawatan kulit wajah kering dan mempunyai kriteria warna putih kecokelatan, beraroma harum dan enak, tekstur yang sangat halus, lembab, elastisitas yang baik terasa kencang dan kenyal, serta kondisi kulit yang membaik pada treatment ke 3 dan disukai oleh responden.
\end{abstract}

Kata kunci : masker, jagung, madu, kulit kering.

\begin{abstract}
Besides being processed into staple foods and food for livestock, corn can save a variety of good benefits for beauty care. One processed corn that can be utilized is making corn masks and honey for dry facial skin care. This study aims to determine how the physical properties of corn and honey masks which include color, aroma, texture, and panelist preference, analyze the effect of masks of corn and honey on dry facial skin care in terms of skin texture, skin moisture, skin elasticity and determine observer responses against masks and dry facial skin care. This type of research is quantitative by using observation and experimental methods. The population in this study were women aged 20-25 years. Data collection methods used observations and panelists' preference for color, aroma, texture, stickiness of 10 respondents. The results showed that there was an effect of the use of corn masks and honey on dry face skin care and the criteria for brownish white, fragrant and delicious, very smooth, moist texture, good elasticity feels tight and supple, and the skin condition improves at the 3rd treatment and is liked by the respondent.
\end{abstract}

Keywords: masks, corn, honey, dry skin. 


\section{PENDAHULUAN}

Hampir semua wanita di dunia ini sangat menginginkan untuk tampil cantik dan memiliki kulit yang sehat. Sebagian dari mereka, ada yang berani melakukan apa saja untuk mengubah dirinya menjadi cantik seperti yang mereka harapkan. Misalnya, dengan menggunakan berbagai kosmetik, melakukan perawatan tubuh dari ujung rambut sampai ujung kaki, bahkan operasi plastik sekalipun. Maka, tidak heran kalau produk kecantikan yang sering muncul di TV sangat laris di pasaran. Fakta membuktikan bahkan wanita memiliki kebutuhan yang jauh lebih kompleks dibandingkan dengan lakilaki.

Setiap wanita tentu mendambakan kecantikan dan keserasian dalam penampilannya, wajah yang dirawat dengan benar akan menjadi sehat, bersih, dan bercahaya hingga terlihat cantik berseri. Sebaliknya jika kurang dirawat dan dijaga, kesehatan kulit dapat terganggu dan menyebabkan wajah terlihat suram, kotor, dan tidak bercahaya, yang akhirnya dapat mengurangi atau bahkan menghilangkan kecantikan. Kulit normal memiliki ciri-ciri yakni tekstur wajah kenyal, kulit tidak tipis, kulit tidak kering tetapi sedikit berminyak (lembab), halus dan lembut. Kandungan air dan minyak seimbang. Kelembaban sangat terjaga, ukuran pori-pori sangat halus dan tidak besar, tanda-tanda penuaan berjalan sesuai dengan seiring berjalannya usia, serta pada siang hari wajah terlihat bersih dan segar (Adijaya, 2014).

Perawatan wajah harus dimulai sejak dini terutama bagi wanita yang telah menginjak usia 20-an. Dengan berjalannya usia, elastisitas kulit akan menurun ditambah lagi polusi udara semakin parah, sinar matahari lengkap dengan Ultravioletnya semakin menyengat, gaya hidup yang kurang sehat. Itulah sebabnya perlu dilakukan perawatan secara teratur dan menyeluruh untuk 2 merawat dan mempertahankan keindahan dan kesehatan merawat dan mempertahankan keindahan dan kesehatan kulit wajah. Selain itu, kulit juga mencerminkan kecantikan seorang wanita. Wanita yang benar-benar menjaga dan merawat kulitnya akan terlihat lebih cantik dibanding dengan wanita yang tidak melakukannya.

Permasalahan yang seringkali di alami wanita diantaranya adalah kulit wajah yang kering. Kulit wajah yang kering sering menjadi kendala karena terlihat tidak sehat, kusam, dan terkadang sampai bersisik. Perawatan kulit wajah kering yang biasa dilakukan yaitu perawatan kulit secara tradisional maupun modern. Perawatan kulit wajah kering secara modern yang pada umumnya sering dilakukan yaitu pemakaian krim dengan kadar kandungan bahan kimia yang tinggi, hasilnya dapat terlihat hanya dalam jangka waktu yang singkat, sedangkan perawatan secara tradisional yaitu perawatan wajah yang terbuat dari bahan-bahan alami, misalnya ekstrak dari buah-buahan atau sayuran, kuning telur, yoghurt, madu, minyak zaitun dan lain sebagainya yang dipercaya bermanfaat untuk merawat dan memberikan nutrisi pada kulit wajah yang kering.

Semua perawatan kulit wajah memiliki tujuan yang sama yaitu untuk mempertahankan dan meningkatkan kesehatan dan fungsi kulit serta memperindah wujud luarnya, disesuaikan dengan jenis kulit yang bersangkutan. Manfaat penggunaan perawatan alami/herbal yang dapat diambil antara lain sebagai berikut : Pertama, fakta menunjukkan bahwa $87 \%$ bahan kimia yang digunakan di kulit akan terserap sampai ke aliran darah tubuh. Kedua, herbal sangat mudah didapat dan murah. Ketiga, bahannya berasal langsung dari alam maka cenderung tidak memiliki efek samping layaknya obat- 
obatan kimia. Kalaupun ada efek sampingnya, hal itu tidak terlalu berbahaya. Salah satu perawatan alami yaitu menggunakan masker jagung dan madu, khasiat dan kandungan yang terdapat dalam jagung belum diketahui kebanyakan masyarakat dan dipasaran belum ada yang menjual produk masker dari jagung tersebut. Jagung terdapat kandungan thiamin yang bermanfaat dapat mengeringkan luka/noda-noda, misalnya luka pada cacar air dan jerawat. Jagung juga memiliki kandungan prokaroten yang dapat memperbaiki struktur kulit. Selain itu, zat yang ada di dalam jagung juga membantu mengatasi munculnya jerawat tanpa membuat wajah jadi lebih berminyak atau kering, namun dapat dipakai untuk mengatasi permasalahan tersebut adalah jagung muda. . Jagung memiliki kandungan lemak dan proterin sehingga menghasilkan asam amino yang dibutuhkan oleh kulit kering (Saragih, 2016). Jagung yang digunakan dalam penelitian ini jenis jagung muda segar yang berwarna kuning. Selain kandungan jagung yang baik untuk kulit kita jagung juga bahan utama yang mudah untuk di dapatkan dan harganya relative murah.

Dalam perawatan kulit wajah kering selain menggunakan bahan-bahan utama. Pada penelitian ini madu yang digunaka merupakan madu murni yang berasal dari Flores. Menggunakan madu sebagai bahan campuran masker diharapkan akan mendapatkan hasil akhir yang lebih baik dan untuk menutupi kekurangan dari masker jagung. Berdasarkan uraian di atas, bahanbahan tersebut dicampur menjadi eksperimen produk kosmetik untuk perawatan kulit wajah, maka perlu dilakukan penelitian yang berjudul "Pengaruh Penggunaan Masker Jagung dan Madu Terhadap Perawatan Kulit Wajah Kering".

\section{METODE PENELITIAN}

\author{
TA :Tes Awal \\ TAK :Tes Akhir \\ $\mathrm{X}$ :Bahan Eksperimen
}

\section{Populasi dan Sampel}

Populasi dan sampel ditentukan oleh peneliti dengan kriteria yang dipilih sesuai dengan karakteristik dengan penghasil masker yang berkualitas yaitu;

a. Jagung yang digunakan adalah yang berkualitas baik, jagung yang digunakan adalah jagung biasa, muda, berwarna kuning, segar, bersih, tidak busuk.

b. Madu yang digunakan merupan madu murni dari lebah ternak (Apis Mellifera) dari Flores.

c. Wanita yang memiliki masalah kulit wajah yang kering.

d. Responden yang dipilih Wanita berusia antara 20 - 25 tahun.

\section{HASIL DAN PEMBAHASAN}

A. Hasil

\section{Warna Masker Jagung dan Madu}

Berdasarkan Gambar 1. dengan diagram berwarna merah, nilai rata-rata skor sifat fisik warna pada masker jagung dan madu memiliki nilai skor 3,8 dengan kriteria putih kecokelatan. Hal ini dikarenakan warna tepung jagung yang berwarna putih dan madu murni yang berwarna kuning sangat gelap. Sehingga ketika dicampur akan terlihat berwarna putih kecokelatan. Hasil angket uji sifat fisik dari 8 dari 10 observer menyatakan bahwa masker jagung dan madu berwarna putih kecokelatan, sedangkan 2 lainnya mengatakan masker jagung dan madu memiliki warna putih kekuningan.

\section{Aroma Masker Jagung dan Madu}

Berdasarkan Gambar 1. dengan diagram berwarna kuning, nilai rata-rata skor sifat fisik aroma pada masker jagung dan 
madu memiliki nilai skor 4 dengan kriteria beraroma. Hal ini dikarenakan madu yang memiliki aroma sangat manis dan air mawar yang segar. Sehingga ketika dicampur akan beraroma harum. Hasil angket uji sifat fisik dari 10 observer menyatakan bahwa masker jagung dan madu memiliki aroma yang harum tetapi tidak menyengat.

\section{Tekstur Masker Jagung dan Madu}

Berdasarkan Gambar 1. dengan diagram berwarna biru muda, nilai rata-rata skor sifat fisik tekstur pada masker jagung dan madu memiliki nilai skor 4 dengan kriteria sangat halus. Hal ini dikarenakan tepung jagung yang diayak dengan mesh 100 sehingga didapatkan butiran tepung jagung yang sangat halus. Madu dan air mawar juga bahan yang tidak bertekstur kasar. Sehingga ketika dicampurkan, masker jagung dan madu terasa sangat halus. Hasil angket uji sifat fisik dari 10 observer menyatakan bahwa masker jagung dan madu terasa sangat halus.

Analisis data pada penelitian ini menggunakan bantuan SPSS versi 21 bertujuan untuk mengetahui pengaruh penggunaan masker jagung dan madu terhadap perawatan kulit wajah kering. Hasil penelitian berdasarkan penilaian 10 observer yang melakukan perawatan kulit wajah dengan kriteria memiliki kulit wajah kering. Aspek yang dianalisis merupakan tekstur kulit, kelembaban kulit, elastisitas kulit dan pendapat observer. Hasil analisis data ini disajikan dalam Anava Tunggal (One Way Anova), jika terdapat pengaruh yang nyata maka uji dilanjutkan menggunakan uji Duncan.

\section{a.Tekstur Kulit}

Dari data mean tersebut maka dilanjutkan uji One Way Anova dengan menggunakan program SPSS versi 21 untuk mencari perbedaan hasil pada perawatan kulit wajah kering menggunakan masker jagung dan madu, jika terdapat perbedaan maka dilanjutkan uji Duncan.

Tabel 1

Hasil Analisis Data Tekstur Kulit

Penggunaan Masker Jagung dan Madu

Tekstur

Kulit

\begin{tabular}{|c|c|c|c|c|c|}
\hline & $\begin{array}{l}\text { Sum } \\
\text { Squares }\end{array}$ & $\mathrm{df}$ & $\begin{array}{l}\text { Mean } \\
\text { Square }\end{array}$ & $\mathrm{F}$ & Sig. \\
\hline $\begin{array}{l}\text { Between } \\
\text { Groups }\end{array}$ & 6.067 & 2 & 3.033 & $\begin{array}{l}7.72 \\
6\end{array}$ & .002 \\
\hline $\begin{array}{l}\text { Within } \\
\text { Groups }\end{array}$ & 10.600 & 27 & .393 & & \\
\hline Total & 16.667 & 29 & & & \\
\hline
\end{tabular}

Tabel 1 dijelaskan bahwa hasil analisis dengan menggunakan anova tunggal pada hasil perawatan kulit wajah kering yang ditinjau dari tekstur kulit diperoleh $\mathrm{F}_{\text {hitung }}$ sebesar 7.726 dan probabilitas 0,002 lebih kecil dari taraf nyata 0,05 artinya hipotesis yang berbunyi terdapat pengaruh nyata penggunaan masker jagung dan madu pada perawatan kulit wajah kering di tinjau dari tekstur kulit, kelembaban kulit, dan elastisitas kulit diterima.

\section{b. Kelembaban Kulit}

Dari data mean tersebut maka dilanjutkan uji One Way Anova dengan menggunakan program SPSS versi 21 untuk mencari perbedaan hasil kelembaba kulit pada perawatan kulit wajah kering menggunakan masker jagung dan madu, jika terdapat perbedaan maka dilanjutkan uji Duncan.

Tabel 2

Hasil Analisis Data Kelembaban Kulit

Penggunaan Masker Jagung dan Madu

\begin{tabular}{cllll}
\hline Kelembaban Kulit & & & & \\
\hline Sum of & Mean & & \\
Squares & df & Square & F & Sig. \\
\hline
\end{tabular}


Volume 71, Nomor 1, 1 Juni 2019

\begin{tabular}{llllll}
\hline $\begin{array}{l}\text { Between } \\
\text { Groups }\end{array}$ & 5.267 & 2 & 2.633 & $\begin{array}{l}5.82 \\
8\end{array}$ & .008 \\
\hline $\begin{array}{l}\text { Within } \\
\text { Groups }\end{array}$ & 12.200 & 27 & .452 & & \\
\hline Total & 17.467 & 29 & & & \\
\hline
\end{tabular}

Tabel 2 dijelaskan bahwa hasil analisis dengan mennggunakan anova tunggal pada hasil perawatan kulit wajah kering yang ditinjau dari kelembaban kulit diperoleh $F_{\text {hitung }}$ sebesar 5.828 dan probabilitas 0,008 lebih kecil dari taraf nyata 0,05 maka artinya hipotesis yang berbunyi terdapat pengaruh nyata penggunaan masker jagung dan madu pada perawatan kuli wajah kering di tinjau dari tekstur kulit, kelembaban kulit, dan elastisitas kulit diterima.

\section{c. Elastisitas Kulit}

Dari data mean tersebut maka dilanjutkan uji One Way Anova dengan menggunakan program SPSS versi 21 untuk mencari perbedaan hasil elastisitas kulit pada perawatan kulit wajah kering menggunakan masker jagung dan madu, jika terdapat perbedaan maka dilanjutkan uji Duncan.

\section{Tabel 3}

Hasil Analisis Data Elastisitas Kulit

Penggunaan Masker Jagung dan Madu

\begin{tabular}{|c|c|c|c|c|}
\hline \multicolumn{5}{|c|}{ Pendapat Observer } \\
\hline & $\begin{array}{l}\text { Sum } \\
\text { Squares }\end{array}$ & Df & $\begin{array}{l}\text { Mean } \\
\text { Square }\end{array}$ & Sig. \\
\hline $\begin{array}{l}\text { Between } \\
\text { Groups }\end{array}$ & 4.200 & 2 & 2.100 & 5.614 .009 \\
\hline $\begin{array}{l}\text { Within } \\
\text { Groups }\end{array}$ & 10.100 & 27 & .374 & \\
\hline Total & 14.300 & 29 & & \\
\hline
\end{tabular}

Tabel 3 dijelaskan bahwa hasil analisis dengan mennggunakan anova tunggal pada hasil perawatan kulit wajah kering yang ditinjau dari elastisitas kulit diperoleh $\mathrm{F}_{\text {hitung }}$ sebesar 5.700 dan probabilitas 0,009 lebih kecil dari taraf nyata 0,05 maka artinya $\mathrm{Ha}$ diterima. Sehingga hipotesis yang berbunyi terdapat pengaruh nyata penggunaan masker jagung dan madu pada perawatan kulit wajah kering di tinjau dari tekstur kulit, kelembaban kulit, dan elastisitas kulit diterima.

\section{Tanggapan Observer Terhadap Perawata Kulit Wajah Kering Menggunakan Masker Jagung Dan Madu}

Dari data mean tersebut maka dilanjutkan uji One Way Anova dengan menggunakan program SPSS versi 21 untuk mencari perbedaan hasil pendapat observer pada perawatan kulit wajah kering menggunakan masker jagung dan madu, jika terdapat perbedaan maka dilanjutkan uji Duncan.

Tabel 4.

Hasil Analisis Data Pendapat Observer Penggunaan Masker Jagung dan Madu

ElastisitasKulit

\begin{tabular}{llllll}
\hline & $\begin{array}{l}\text { Sum of } \\
\text { Squares }\end{array}$ & df & $\begin{array}{l}\text { Mean } \\
\text { Square }\end{array}$ & F & Sig. \\
\hline $\begin{array}{l}\text { Between } \\
\text { Groups }\end{array}$ & 3.800 & 2 & 1.900 & 5.700 .009 \\
\hline Within Groups & 9.000 & 27 & .333 & \\
\hline Total & 12.800 & 29 & & \\
\hline
\end{tabular}

Tabel 4 dijelaskan bahwa hasil analisis dengan mennggunakan anova tunggal pada hasil perawatan kulit wajah kering yang ditinjau dari pendapat observer diperoleh $F_{\text {hitung }}$ sebesar 5.614 dan probabilitas 0,009 lebih kecil dari taraf nyata 0,05 maka artinya hipotesis yang berbunyi tanggapan observer terhadap perawatan kulit wajah kering menggunakan masker jagung dan madu di terima dan suka. 


\section{B. PEMBAHASAN}

\section{Hasil Sifat Fisik Masker Jagung dan} Madu

\section{a. Warna}

Berdasarkan Gambar 1, nilai rata-rata warna terhadap hasil masker jagung dan madu memiliki skor 3,8. Hasil angket uji sifat fisik dari 10 observer menyatakan bahwa masker wajah berbahan dasar jagung dan madu memiliki warna putih kecokelatan.

\section{b. Aroma}

Berdasarkan Gambar 1, nilai rata-rata aroma terhadap hasil sifat fisik masker jagung dan madu adalah 4. Hasil angket uji sifat fisik dari 10 observer, 10 observer menyatakan aroma pada masker jagung dan madu adalah beraroma harum dan enak.

\section{c. Tekstur}

Berdasarkan Gambar 1, nilai rata-rata tekstur terhadap hasil sifat fisik masker jagung dan madu adalah 4 yaitu halus. Hasil angket uji sifat fisik dari 10 observer, 10 observer menyatakan bahwa sifat fisik masker jagung dan madu terhadap tekstur adalah sangat halus.

\section{Pengaruh Penggunaan Masker Jagung Dan Madu Terhadap Perawatan Kulit Wajah Kering}

Pada bagian ini dijelaskan pembahasan hasil analisis data statistik klasifikasi tunggal dan Duncan tentang "Pengaruh Penggunaan Masker Jagung dan Madu Terhadap Hasil Perawatan Kulit Wajah Kering". Adapun pembahasan dari keseluruhan adalah sebagai berikut:

\section{a. Tekstur Kulit}

Berdasarkan hasil analisis data menunjukan bahwa perawatan kulit wajah kering dengan masker jagung dan madu dari aspek tekstur kulit menunjukan bahwa treatment X3 berada pada subset dengan nilai rata-rata tertinggi yaitu 3,9 dengan menghasilkan kriteria tekstur kulit yang halus. Hal ini disebabkan perubahan kondisi tekstur kulit yang kering adalah kasar menjadi halus seperti kulit normal karena perawatan kulit wajah kering menggunakan masker jagung dan madu.

\section{b. Kelembaban Kulit}

Berdasarkan hasil analisis data menunjukan bahwa perawatan kulit wajah kering dengan masker jagung dan madu dari aspek kelembaban kulit menunjukan bahwa treatment X3 berada pada subset dengan nilai rata-rata tertinggi yaitu 3,7 dengan menghasilkan kriteria kelembaban kulit yang lembab. Hal ini disebabkan perawatan kulit wajah kering dengan masker jagung dan madu secara rutin sehingga terdapat perbedaan hasil yang nyata di setiap treatmentnya.

\section{c. Elastisitas Kulit}

Berdasarkan hasil analisis data menunjukan bahwa perawatan kulit wajah kering dengan masker jagung dan madu dari aspek elastisitas kulit menunjukan bahwa treatment X3 berada pada subset dengan nilai rata-rata tertinggi yaitu 3,7 dengan menghasilkan kriteria elastis terasa kenyal dan kencang. Hal ini juga disebabkan perawatan kulit wajah kering dengan menggunakan jagung dan madu.

3. Tanggapan Observer Terhadap Sifat Fisik Masker dan Hasil Perawata Kulit Wajah Kering Menggunakan Masker Jagung Dan Madu

Berdasarkan Gambar 1, nilai rata-rata kesukaan observer terhadap hasil jadi masker jagung dan madu adalah 4 yang memiliki kriteria penilaian disukai oleh observer. Hasil pengamatan oleh 10 observer mengatakan menyukai hasil masker jagung dan madu sebab memiliki aroma yang enak sebab zat aromatik madu berupa minyak esensial, campuran karbonil (formaldehid, asetaldehid, propionaldehid, aseton, metil etil keton, dan sebagainya), ikatan alkohol (propanol, etanol, 
butanol, isobutanol, pentanol, benzyl alkohol, dan sebagainya), serta ikatan ester (asam benzoat atau propionat). (Hariyati, 2010).

\section{KESIMPULAN}

Berdasarkan hasil observasi, analisis data serta pembahasan tentang pengaruh penggunaan masker jagung dan madu terhadap perawatan kulit wajah kering, maka dapat disimpulkan sebagai beikut :

1. Menurut hasil data observasi pada sifat fisik masker jagung dan madu terhadap perawatan kulit wajah kering mempunyai kriteria warna putih kecokelatan, beraroma harum dan enak, tekstur yang sangat halus, dan disukai oleh observer.

2. Menurut hasil penelitian terdapat pengaruh penggunaan masker jagung dan madu terhadap perawatan kulit wajah kering dengan kriteria kulit menjadi halus, lembab, elastisitas yang baik terasa kencang dan kenyal, serta kondisi kulit yang membaik pada treatment ke 3 .

3. Menurut hasil penelitian tanggapan observer terhadap perawatan kulit wajah kering menggunakan masker jagung dan madu di terima dan suka Sebab adanya perubahan kondisi pada kulit wajah menjadi lebih lembab, halus dan memiliki elastisitas kulit yang baik.

\section{REFERENSI}

Arikunto, S. (2010). Prosedur Penelitian Suatu Pendekatan Praktik. Jakarta: Rineka Cipta.

Astuti, M. (1999). "Perbandingan Hasil Kehalusan Kulit Kering Antara Yang Menggunakan Masker Penambahan Pisang Ambon Dengan Tepung Jagung Kuning
Dan Masker Penambahan Pisang Ambon Dengan Tepung Jagung Putih". Jurnal Univeristas Negeri Padang.

Eddi. (1999). Teknik membuat Kosmetik dan

Tip kecantikan Kulit. Jakarta: PT. Rineka Cipta.

Eleazu, C.O., et al. (2013). "Determination Of The Physicochemical Composition Microbial Quality And Free Radical Scavenging Activities Of Some Commercially Sold Honey Samples In Aba Nigeria. The Effect Of Varying Colours". International Journal of Biomedical Research 4(1): 32-41.

Hariyati, L.F. (2010). "Aktivitas Antibakteri Berbagai Jenis Madu Terhadap Mikroba Pembusuk (Pseudomonas Fluorescens Fncc 0071 Dan Pseudomonas Putida Fncc 0070)". Jurnal Fakultas Pertanian Universitas Sebelas Maret Surakarta.

Kusumadewi. (2002). Perawatan dan Tata Rias Wajah Wanita Usia 40+. Jakarta: PT.Gramedia Pustaka Utama

Sugiyono. (2012). Metode Penelitian Kuantitatif Kualitatif dan $R \& D$. Bandung: Alfabeta.

Siwi, D. B., dkk. (2018). "Madu". Magister Ilmu Fisika Fakultas Sains dan Matematika Universitas Diponegoro. 
Volume 71, Nomor 1, 1 Juni 2019 